\title{
Superficial morphology and mechanical properties of in vivo aged orthodontic ligatures
}

\author{
Glaucio Serra Guimarães ${ }^{1}$, Liliane Siqueira de Morais², \\ Margareth Maria Gomes de Souza 3 , Carlos Nelson Elias ${ }^{4}$
}

Introduction: The degradation of elastic ligatures in the oral environment results in the need of periodic replacement to maintain the optimal force during the orthodontic treatment. The purpose of this study was to perform a clinical prospective randomized study of the degradation of orthodontic elastomeric ligatures in the oral environment by scanning electron microscopy (SEM) and tensile strength test. Method: Two hundred elastic ligatures were randomly selected and placed around the brackets of 5 volunteers and removed in groups of 10 , at different times (1,2,3, and 4 weeks). The control group was performed by another fifty ligatures which were not submitted to the oral degradation. The analyses were done by scanning electron microscopy (SEM) and strength mechanical test. Results: The tensile strength test results showed reduction in the ultimate strength values after four weeks ageing in the oral environment and no statistical difference in the yield strength values $(\mathrm{p}<0.05)$. The orthodontic elastomeric ligatures surface was significantly degraded in the oral cavity after four weeks. The elastomeric degradation began in the first week when the increase in the roughness could be detected just in some areas. Afterwards, the surface became gradually rougher and, after 4 weeks, it was totally rough with some crack areas. Conclusions: The elastic ligatures aged in the oral environment showed higher superficial degradation and lower loss of mechanical properties after the maximum experimental period.

Keywords: Elastomers. Elastic ligature. Degradation.

Introdução: a degradação das ligaduras elásticas no ambiente bucal resulta na necessidade de substituição periódica para manter-se a força ótima durante o tratamento ortodôntico. Objetivo: a proposta desse trabalho foi realizar um estudo clínico prospectivo randomizado da degradação de ligaduras elásticas ortodônticas envelhecidas no ambiente bucal por microscopia eletrônica de varredura e por ensaio de tração. Métodos: duzentas ligaduras foram randomicamente selecionadas e inseridas ao redor dos braquetes de 5 pacientes voluntários e, então, removidas, em grupos de 10 , após diferentes tempos (1, 2, 3 e 4 semanas). O grupo controle foi formado por outras 50 ligaduras que não foram submetidas à degradação intrabucal. Resultados: o ensaio mecânico demonstrou diminuição no limite de resistência à fratura após 4 semanas de degradação e não demonstrou diferença estatisticamente significativa no limite de elasticidade. A análise por microscopia eletrônica de varredura revelou que a superfície dos elastômeros tornou-se significativamente degradada após 4 semanas. A degradação teve início na primeira semana, quando o acréscimo de rugosidade superficial pôde ser detectado em algumas áreas. Posteriormente, a superfície tornou-se gradativamente mais rugosa, sendo que após 4 semanas toda a região apresentou-se rugosa e com algumas fraturas superficiais. Conclusões: as ligaduras elásticas envelhecidas no ambiente bucal apresentaram maior degradação superficial e menor perda das propriedades mecânicas após o período experimental máximo.

Palavras-chave: Elastômero. Ligadura elástica. Degradação.

\footnotetext{
${ }^{1}$ Adjunct Professor, Fluminense Federal University.

${ }^{2} \mathrm{PhD}$ in Materials Science, IME.

${ }^{3}$ Adjunct Professor of Orthodontics, Federal University of Rio de Janeiro.

${ }^{4}$ Adjunct Professor, Militar Institute of Engineering.

» The authors report no commercial, proprietary or financial interest in the products or companies described in this article.
}

How to cite this article: Guimarães GS, Morais LS, Souza MMG, Elias CN. Superficial morphology and mechanical properties and of in vivo aged orthodontic ligatures. Dental Press J Orthod. 2013 May-June;18(3):107-12.

Submitted: May 29, 2010 - Revised and accepted: February 21, 2011

Contact address: Glaucio Serra Guimarães Av. Nossa Senhora de Copacabana, 647 - Sl. 1108 - Copacabana CEP: 22.050-901 - Rio de Janeiro/RJ - Brazil

E-mail: gserrag@hotmail.com 


\section{INTRODUCTION}

Polymeric materials have been used in Orthodontics since $1893^{14,15}$ and the elastomers are the main polymers used in it. Orthodontic tooth movement is achieved by low force application for long periods, and the elastomers are the most used method to supply orthodontic force in the tooth movement. ${ }^{21}$ Its use is related to the transformation of elastic potential energy in mechanical energy, resulting in tooth movement. ${ }^{3,12}$

Natural rubber (NR) was commercially produced in the beginning of the last century through cultivation and puncture of the rubber tree (Haevea brasiliensis), in Amazon, Brazil. The natural polymer synthesized from Haevea species has a high molecular weight average of nearly a million. It is composed of 3 transisoprene units at the end of the molecule and of several thousands of cis-isoprene units in the main chain.

Synthetic isoprene rubber (SR) is a polymer with cis-isoprene units combined by 1,4-linkages. ${ }^{4}$ The SR has better properties than NR to orthodontic use. ${ }^{16}$ Synthetic rubbers are the most used orthodontic polymer because they produce optimal force, are comfortable, are easy to clean and have low cost. ${ }^{19}$ Nevertheless, these materials have quick degradation in the oral cavity and, consequently, short lifetime, which is a notable disadvantage. The main causes of the quick degradation are the variation on $\mathrm{pH}$ and temperature, the humidity of the environment, the stress, and the bacterial action. ${ }^{7}$

The complex conditions present in the oral cavity cause degradation in elastomers. Some factors of this environment as humidity and temperature can be simulated in vitro, but others such as the presence of complex flora and its products can not be. These in vivo factors are able to induce substantial alterations in the structure and surface of elastomers. ${ }^{10}$

Thus, the purpose of the present work was to investigate the degradation of orthodontic elastomeric ligatures in the oral environment by scanning electron microscopy (SEM) and tensile strength test.

\section{MATERIAL AND METHODS}

Two hundred and fifty elastomeric ligatures obtained from manufacturer (TP Orthodontics, Indiana, USA) were randomly distributed in 5 equal groups composed by fifty test specimens each. Five volunteers who had not had any complicating medi- cine and had not used antibiotics in the last 2 months were selected from patients about to start their orthodontic treatment with fixed appliances in orthodontic department of Rio de Janeiro Federal University. The patients were invited to participate in the study during 6 weeks. After approval, written consent was given by patient in the moment of placement of appliances. Forty elastomers were kept in the oral cavity of each patient for 1, 2, 3 or 4 weeks and the control group were not placed in the oral environment.

At the first visit, 20 orthodontic elastomeric ligatures were randomly selected and placed around the brackets in the oral cavity from the second premolar on one side to the second premolar on the opposite side, in both arches.

At the second appointment, after one week, 10 ligatures were pulled out (week-1 group). Five of them were evaluated by scanning electron microscopy to analyze the changes in the superficial morphology caused by oral degradation. The other five were submitted to tensile strength test to analyze the changes in the mechanical properties. At the same appointment, 10 new elastomeric ligatures were placed around the brackets which had the ligatures pulled out.

At the third visit, 10 ligatures which have been in the oral cavity for 2 weeks were pulled out (week2 group) and analyzed in the same way of the first group. At this moment, 10 new ligatures were placed around the brackets.

After 2 weeks, in the fourth appointment, 10 ligatures which have been in the oral cavity for 3 weeks were pulled out (week-3 group) and analyzed as the other groups.

In the last appointment, after 2 weeks more, the ligatures that have been in the oral cavity for 4 weeks were removed (week-4 group) and analyzed by scanning electron microscopy and tensile strength test.

The tensile test was performed in ambient temperature, in a universal test machine (Emic DL 10000, Brazil) with cross-head speed of $2 \mathrm{~mm} / \mathrm{min}$ and load cell of $50 \mathrm{~N}$. A pair of hooks was done with stainless steel (0.032-in diameter) and adapted in the test machine $^{11}$ (Fig 1). The yield strength and the ultimate strength were used as parameters of the tensile test. ${ }^{21}$ Tensile strength data were statistically analyzed using one-way ANOVA and compare means with Tukey post hoc test, ${ }^{5}$ based on significance level of $0.05 \%$. 


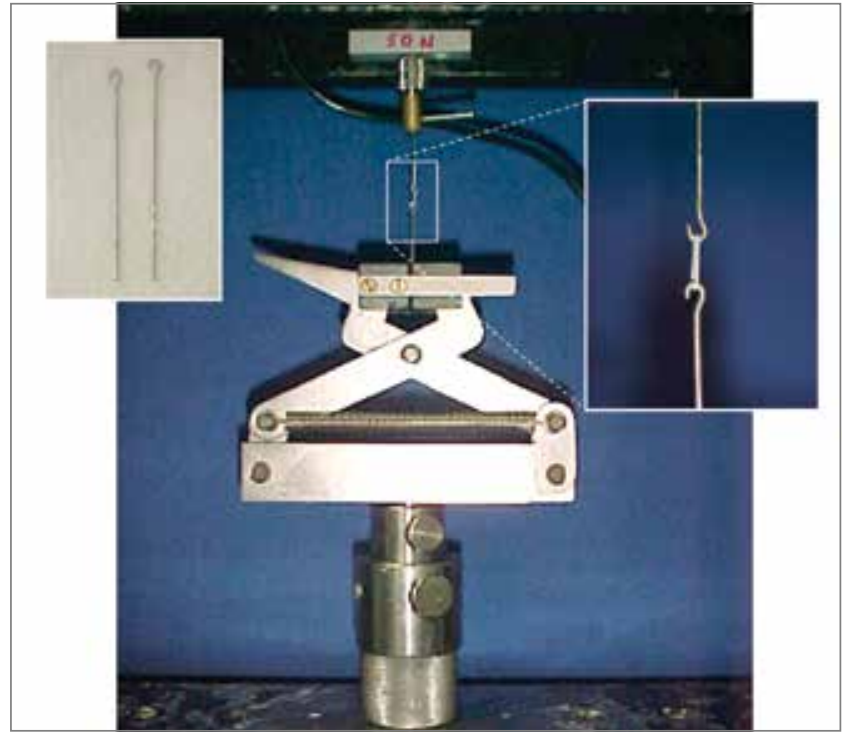

Figure 1 - Tensile strength test adapted with two stainless steel hooks (0.032 inch).

For surface degradation analysis, the test specimens were coated with gold for 3 minutes at a current of $20 \mathrm{~m} \AA$ and vacuum of $200 \mathrm{mTorr}$. The images were obtained by secondary electrons detector using a scanning electron microscope (JSM 5800, Jeol, Tokyo, Japan). ${ }^{23}$

\section{RESULTS}

The analysis gave evidences of higher superficial degradation than mechanical properties loss. The tensile strength test results showed few mechanical properties changes in both parameters. The ultimate strength values demonstrated no statistical difference among control, week-1, week-2, and week-3 groups. Although, the week-4 group had been significantly lower than the other groups. The values of yield strength did not show any statistical difference among all groups (Fig 2).

The surface analysis showed gradual degradation indicated by the increase of superficial roughness. Effects of viscoelastic fluency were detectable after the first week and became more intense with increase of the oral permanency time. The superficial roughness raised in specific points in the week-1 group. The week-2 and week-3 groups demonstrated higher area of roughness. In the week-4 group, cracks were visible in elastomeric surfaces and the entire elastomeric surface was rough (Fig 3).

\section{DISCUSSION}

The surface morphology of the elastic ligatures has been significantly changed after the normal use in the oral environment during progressive intervals.
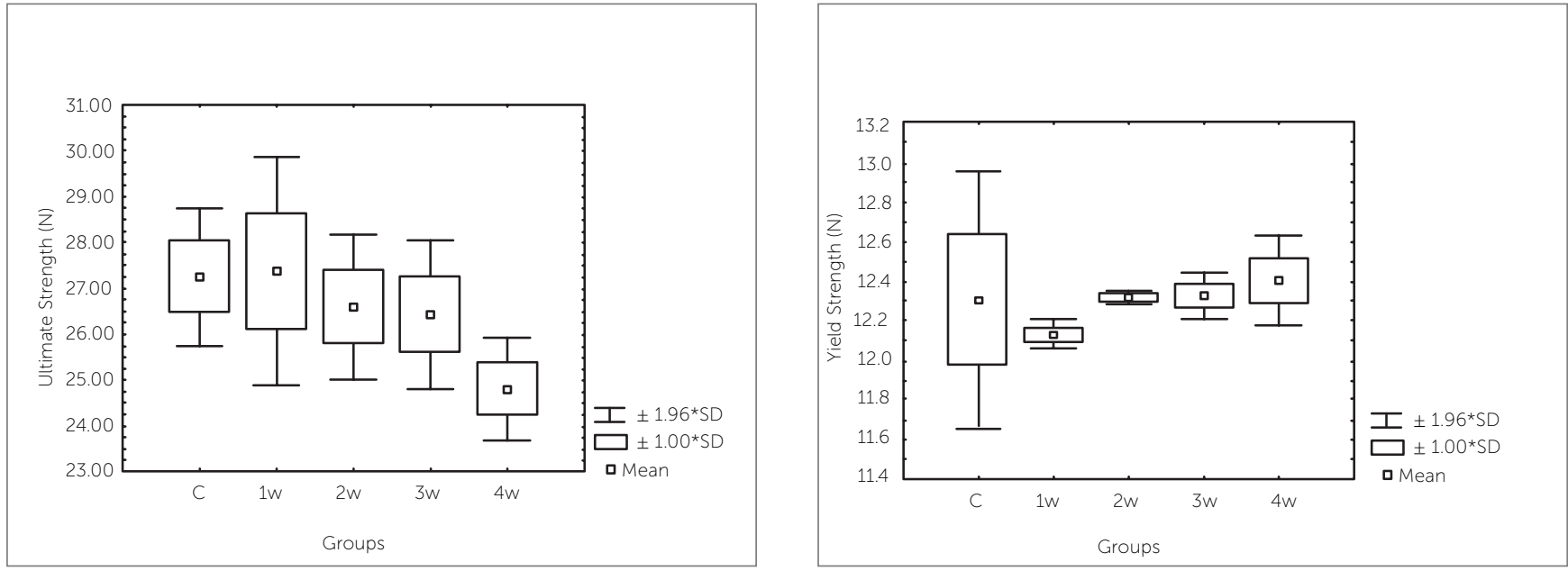

Figure 2 - Box plot graph: difference in ultimate strength and yield strength among groups. 


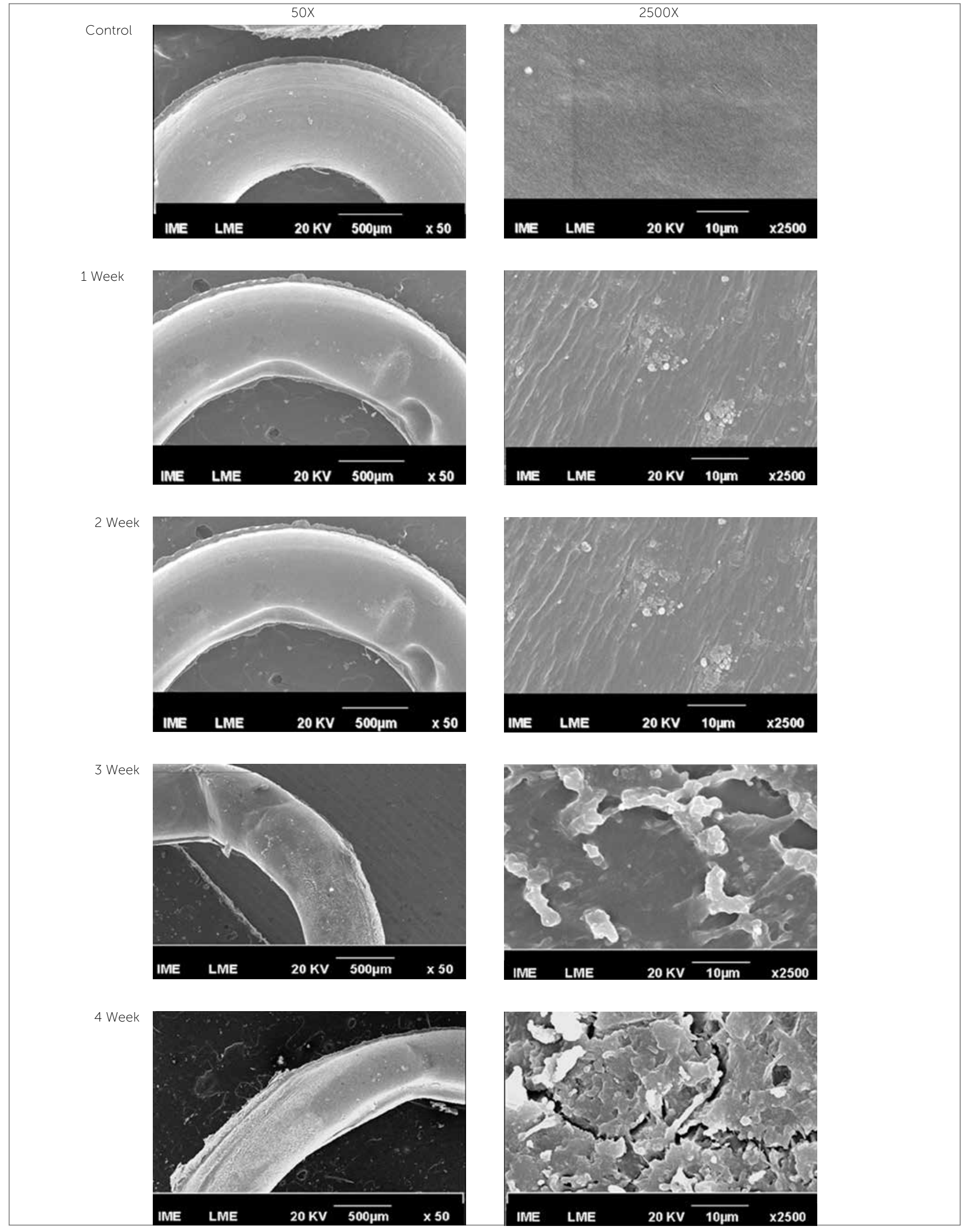

Figure 3 - SEM surface morphology photomicrographs (electron secondary image). Control group: The superficial smoothness of the elastomer; Week-1 group: The effects of viscoelastic fluency are apparent in some specific points; Week-2 group: The increase of deformation points and the presence of biofilm above the elastomer are visible; Week-3 group: The superficial roughness is significantly higher and the thickness of the elastomer is decreased; Week-4 group: The degradation of the elastomer is clearly identified for cracks and roughness in the total area. 
This in-use biomaterial changes were caused by a process known as aging. In the present study the elastic ligatures aging was characterized by the gradual increase in the surface roughness and by few changes in the mechanical properties of the material. Comparing the results of the tensile test and of the SEM analysis, one may suggest that elastomers have higher superficial degradation than loss of mechanical properties.

The orthodontic elastomers are biodegraded in the oral environment mainly by hydrolyses. Their secondary links are broken and the result is the relaxation, ${ }^{2,13}$ which is the main characteristic of degradation in orthodontics elastomers. This phenomenon is responsible for the constant replacements of the elastomeric ligatures. The relaxation consequence is the decrease on mechanical energy transmitted to the tooth and finally, the reduction of effectiveness of the tooth movement. ${ }^{2,11,13,14}$ After relaxation, the elastomers commonly suffer the effects of viscoelastic fluency. This phenomenon consists in plastic deformation when the elastomer is submitted to forces below the plastic limit. ${ }^{6,17}$ Clinically, this effect could be observed in SEM figures. Permanent deformities are visible in all ligatures submitted to the oral environment, although none of them was stressed above their plastic limit (Fig 3).

Hwang and Cha, ${ }^{14}$ in an in vitro study, observed quick relaxation in elastic chains. The author described reduction of $50 \%$ on the initial force in the first 24 hours. Andreasen and Bishara, ${ }^{1}$ in an in vivo study, described reduction of $74 \%$ on initial force after the same degradation time. Some important degradation mechanisms are present just in the oral ambient. In example, the accumulation of plaque on the elastomers and the prolonged contact with enzymes cause significant degradation in these biomaterials. ${ }^{11}$ In the present study, a gradual increase of superficial roughness occurred between 1 and 4 weeks. Eliades et a ${ }^{10}$ described that elastomeric surfaces were modified by irreversible adsorption of proteinaceous matter forming a biofilm after 24 hours in oral cavity. After 3 weeks, this biofilm on elastomeric surface exhibited excessive mineralization increasing the surface roughness. ${ }^{10}$ In agreement, the SEM figures of week-1, 2, 3 and 4 groups exhibited increase of roughness and it could be caused by formation of the mineralized biofilm.
Some factors present in the oral environment as the intermittent stress of the elastomers, the $\mathrm{pH}$, the oxygen content and the temperature variation are related to the relaxation. Although, the increase on the temperature is the most significant point of the degradation mechanism. ${ }^{16,18,22}$ De Genova et al, ${ }^{8}$ related that the temperature in the oral cavity could vary from 0 to $64{ }^{\circ} \mathrm{C}$. In this manner, one important aspect of oral degradation is the variation of the oral environment temperature and it depends on each individual. ${ }^{11}$ In spite of the patients have different eating habits, in the present work, it was observed similar viscoelastic fluency effects in the elastomeric ligatures of all patients. The increase in the internal diameter and reduction in the thickness of ligatures were clearly detected after the first week in the oral cavity. This degradation increased gradually, with the increase of permanency time in the oral environment (Fig 3).

Other important polymeric degradation mechanism occurs in the immersion in water solution as the saliva. This mechanism is pointed out by swelling and dissolution. The liquid is absorbed by the polymer, penetrating among the macromolecules. This produces an internal force that separates the chains and expands the polymer by breaking the secondary links resulting on relaxation. ${ }^{4}$

The degradation of orthodontic elastomers can also occur by oxidation resulting in superficial cracks. The oxidation consists in the interaction among the elastomeric macromolecules with ozone and oxygen. The mechanism responsible for the chemical degradation is the scission of macromolecules chains, in the couple bond between carbon atoms, preferentially attacked by ozone. ${ }^{4}$ In this study, it was observed cracks on the surface of orthodontic elastomeric ligatures of week-4 group. These elastomeric ligatures were not totally immersed in oral fluids during its use. Thus, they have partial contact with air and consequently with ozone and oxygen, that are factors of degradation.

The presence of bacterial flora is another important factor of degradation. Bode et $\mathrm{al}^{4}$ isolated a lot of bacterium able to degraded natural and synthetic rubber. Most of them are present in the oral environment, accelerating the biodegradation process.

The complex oral environment results in degradation with many variables like temperature, bac- 
terium, enzymes, $\mathrm{pH}$, stress, chemical contents and others. More researches are necessary to produce new types of elastomers able to resist in this environment.

\section{CONCLUSIONS}

The elastic ligatures aged in the oral environment showed higher superficial degradation and lower loss of mechanical properties after the maximum experimental period.

The clinically significant result is that after the first week in the oral cavity, the elastomeric ligatures already presented significant superficial degradation and this process gradually increases resulting in significant superficial roughness, supporting plaque accumulation.
1. Andreasen GF, Bishara S. Comparison of alastik chains with elastics involved with intra-arch molar to molar forces. Angle Orthod. 1970;40(3):151-8.

2. Baty DL, Storie DJ, von Fraunhofer JA. Synthetic elastomeric chains: a literature review. Am J Orthod Dentofacial Orthop. 1994;105(6):536-42.

3. Beattie S, Monaghan P. An in vitro study simulating effects of daily diet and patient elastic band change compliance on orthodontic latex elastics. Angle Orthod. 2004;74(2):234-9

4. Bode HB, Kerkhoff $K$, Jendrossek D. Bacterial degradation of natural and synthetic rubber. Biomacromolecules. 2001;2(1):295-303.

5. Calado V, Montgomery DC. Projection of experiments using the Statistic. 1st ed. Rio de Janeiro: E-papers Services; 2003

6. Callister WD. Materials science and engineering: an introduction. 50th ed St. Louis: John Willey \& Sons; 2000.

7. Coffelt MP. The effects of artificial saliva and topical fluoride treatments on the degradation of the elastic properties of orthodontic chains. Angle Orthod. 1992:62(4):265-74.

8. De Genova DC, Mclnnes-Ledoux P, Weinberg R, Shaye R. Force degradation of orthodontic elastomeric chains: a product comparison study. Am J Orthod. 1985;87(5):377-84.

9. Eliades T, Bourauel C. Intraoral aging of orthodontic materials: the picture we miss and its clinical relevance. Am J Orthod Dentofacial Orthop. 2005:127(4):403-12

10. Eliades T, Eliades G, Silikas N, Watts DC. Tensile properties of orthodontic elastomeric chains. Eur J Orthod. 2004;26(2):157-62

11. Eliades T, Eliades G, Watts DC. Structural conformation of in vitro and in vivo aged orthodontic elastomeric modules. Eur J Orthod. 1999:21(6):649-58

12. Graber TM, Vanarsdall RL. Orthodontics: current principles and techniques. 3rd ed. St Louis: Mosby; 2000

13. Howard RS, Nicolai RJ. On the relaxation of orthodontic elastic threads. Angle Orthod. 1979;49(3):167-72.
14. Hwang CJ, Cha JY. Mechanical and biological comparison of latex and silicone rubber bands. Am J Orthod Dentofacial Orthop. 2003:124(4):379-86

15. Kanchana P, Godfrey K. Calibration of force extension and force degradation characteristics of orthodontic latex elastics. Am J Orthod Dentofacial Orthop. 2000;118(3):280-7

16. Kersey ML, Glover K, Heo G, Raboud D, Major PW. An in vitro comparison of 4 brands of nonlatex orthodontic elastics. Am J Orthod Dentofacial Orthop. 2003:123(4):401-7

17. Mano BS, Mendes LC. Introduction for polymers. 2nd ed. São Paulo: Edgard Blücher; 2001.

18. Nattrass C, Ireland AJ, Sherriff M. The effect of environmental factors on elastomeric chain and nickel titanium coil springs. Eur J Orthod. 1998:20(2):169-76

19. Ferreira Neto JJ, Caetano MT. A degradação da força de segmentos de elásticos em cadeia de diferentes tamanhos: estudo comparativo in vitro. J Bras Ortodon Ortop Facial. 2004;9(51):225-33.

20. Proffit WR, Fields HJ. Contemporary orthodontics. 2nd ed. St Louis: Mosby; 1986

21. Russell KA, Milne AD, Khanna RA, Lee JM. In vitro assessment of the mechanical properties of latex and non-latex orthodontic elastics. Am J Orthod Dentofacial Orthop. 2001:120(1):36-44.

22. Stevenson JS, Kusy RP. Force application and decay characteristics of untreated and treated polyurethane elastomeric chains. Angle Orthod 1994:64(6):455-64

23. Suarez JM, Mano EB. Characterization of degradation on gammairradiated recycled polyethylene blends by scanning electron microscopy. Polymer Degrad Stabil. 2001;72:217-21. 